\title{
DAYA DUKUNG PONDASI TIANG PANCANG DENGAN METODE STATIS MENGGUNAKAN DATA LABORATORIUM
}

\author{
Muhammad Khairi ${ }^{1}$ Devi Sundary ${ }^{2}$ Hendra Gunawan ${ }^{3}$ \\ ${ }^{1}$ Mahasiswa, Jurusan Teknik Sipil, Universitas Syiah Kuala, Banda Aceh 23111, Indonesia \\ ${ }^{2,3}$ Dosen, Jurusan Teknik Sipil, Universitas Syiah Kuala, Banda Aceh 23111, Indonesia \\ Email: m.khairi@mhs.unsyiah.ac.id
}

\begin{abstract}
Building is a type of construction that is often encountered, many public facilities are in the form of buildings. The object of this research is PT Bank Aceh Syariah Building which will be built on Jalan Tgk. Daud Beureueh, Kuta Alam District, Banda Aceh City. As a public facility, this building is planned to accommodate many people, so it is important to pay attention to the safety of this building's construction. It is important to calculate the bearing capacity of the foundation as a substructure of the building. The purpose of this study was to analyze the bearing capacity of the pile foundation using a combination of Meyerhoff - Alpha, Meyerhoff - Lamda, and Meyerhoff - Beta static methods. The Meyerhoff method is used to calculate the end resistance, while the Alpha, Lambda, and Beta methods are used to calculate the frictional resistance. This study uses a pile diameter of $0.4 \mathrm{~m}$ and $0.5 \mathrm{~m}$ in the calculation of the carrying capacity. The data used is laboratory data BH-01 and BH-03 at the location of the planned construction of this building, which contains variables in calculating the bearing capacity of the foundation, namely parameters of shear strength, index properties of the soil, and so on. Based on the calculation results, the smallest bearing capacity is obtained by the Meyerhoff - Beta method on BH-03 with a pile diameter of $0.4 \mathrm{~m}$ at a depth of $20 \mathrm{~m}$ with $Q_{u}=101.344$ tons and $Q_{a}=40.538$ tons, while the largest bearing capacity is obtained by the Meyerhoff - Alpha on $B H-01$ with a pile diameter of $0.5 \mathrm{~m}$ at a depth of $30 \mathrm{~m}$ with $Q_{u}=323.412$ tons and $Q_{a}=129.365$ tons.
\end{abstract}

Keywords: bearing capacity, pile foundation, static method, laboratory data

\begin{abstract}
Abstrak
Gedung adalah jenis konstruksi yang paling sering dijumpai, banyak fasilitas umum berwujud gedung. Objek penelitian ini adalah Gedung PT Bank Aceh Syariah yang akan dibangun di Jalan Tgk. Daud Beureueh, Kecamatan Kuta Alam, Kota Banda Aceh. Sebagai fasilitas publik, gedung ini direncanakan dapat menampung banyak orang, sehingga keamanan konstruksi gedung ini penting untuk diperhatikan. Oleh karena itu, perhitungan daya dukung pondasi sebagai struktur bawah gedung ini penting untuk dilakukan. Tujuan penelitian ini adalah menganalisis daya dukung pondasi tiang pancang menggunakan kombinasi metode statis Meyerhoff - Alpha, Meyerhoff - Lamda, dan Meyerhoff - Beta. Metode Meyerhoff digunakan untuk menghitung tahanan ujung, sedangkan metode Alpha, Lamda, dan Beta untuk menghitung tahanan gesek. Penelitian ini menggunakan diameter tiang 0,4 $\mathrm{m}$ dan $0,5 \mathrm{~m}$ dalam perhitungan daya dukung. Data yang digunakan adalah data laboratorium BH-01 dan $\mathrm{BH}-03$ pada lokasi rencana pembangunan gedung ini, yang berisi variabel dalam menghitung daya dukung pondasi, yaitu parameter kuat geser, index properties tanah, dan sebagainya. Berdasarkan hasil perhitungan, daya dukung terkecil diperoleh dengan metode Meyerhoff - Beta pada BH-03 dengan diameter tiang 0,4 m pada kedalaman $20 \mathrm{~m}$ dengan $\mathrm{Q}_{\mathrm{u}}=101,344$ ton dan $\mathrm{Q}_{\mathrm{a}}=40,538$ ton, sedangkan daya dukung terbesar diperoleh dengan metode Meyerhoff - Alpha pada BH-01 dengan diameter tiang 0,5 m pada kedalaman $30 \mathrm{~m}$ dengan $\mathrm{Q}_{\mathrm{u}}=323,412$ ton dan $\mathrm{Q}_{\mathrm{a}}=129,365$ ton.
\end{abstract}

Kata kunci: daya dukung, tiang pancang, metode statis, data laboratorium

\section{Pendahuluan}

Gedung adalah jenis konstruksi yang paling sering dijumpai, ada banyak fasilitas umum yang berwujud gedung. Objek penelitian ini adalah Gedung PT Bank Aceh Syariah, yang direncanakan dibangun di Jalan Tgk. Daud Beureueh, Kecamatan Kuta Alam, Kota Banda Aceh.

Menurut Sosrodarsono [1], beban pada gedung berupa beban mati, beban hidup, beban angin, beban gempa, dan beban khusus. Bahkan beban manusia memberi kontribusi besar, sebab gedung ini adalah fasilitas publik yang direncanakan dapat menampung banyak orang, sehingga keamanan konstruksi gedung ini penting untuk diperhatikan. Oleh karena itu,

Journal of The Civil Engineering Student

Vol. 3. No. 3, Desember 2021, Halaman 287-293 perhitungan daya dukung pondasi sebagai struktur bawah gedung ini penting untuk dilakukan.

Penelitian ini menggunakan pondasi tiang pancang dalam menghitung daya dukung, sebab dari data bore $\log$, N-SPT > 60 rata-rata diperoleh di kedalaman > $20 \mathrm{~m}$. Menurut Bowles [2] hal ini mengindikasikan tanah keras ada di lapisan dalam.

Hardiyatmo [3] Daya dukung dapat dihitung dengan metode statis dan dinamis. Perhitungan dengan metode dinamis dapat dilakukan dengan hasil pemancangan tiang, sedangkan metode statis dapat dilakukan dengan data laboratorium.

Tujuan penelitian ini adalah menganalisis daya dukung pondasi tiang pancang dengan metode statis Meyerhoff untuk memperoleh tahanan ujung, serta 
Alpha, Lamda, dan Beta untuk memperoleh tahanan gesek. Penelitian ini juga menghitung daya dukung berdasarkan diameter tiang $0,4 \mathrm{~m}$ dan $0,5 \mathrm{~m}$.

\section{Tinjauan Kepustakaan}

Pada bab ini diuraikan teori, rumus, serta literatur mengenai daya dukung pondasi tiang pancang dengan metode statis. Masing-masing metode statis memiliki parameter/variabel berbeda dalam perhitungan daya dukung.

\subsection{Pondasi}

Bowles [2] menjelaskan bahwa pondasi merupakan bagian dari suatu konstruksi yang meneruskan beban yang diterima ke dalam tanah maupun batuan yang di bawahnya. Beban tersebut adalah beban yang berasal dari struktur atas maupun beban dari berat pondasi itu sendiri. Semua jenis konstruksi yang direncanakan bertumpu pada tanah harus didukung oleh pondasi.

\subsection{Pondasi tiang pancang}

Menurut Sardjono [4] salah satu jenis pondasi dalam adalah tiang pancang. Tiang pancang adalah jenis pondasi yang berfungsi untuk memindahkan atau mentransfer beban dari konstruksi di atasnya ke lapisan tanah yang lebih dalam.

\subsection{Tegangan vertikal efektif}

Menurut Hardiyatmo [5] tegangan vertikal efektif adalah tegangan akibat berat tanah efektif di dalam tanah. Tegangan ini dapat memengaruhi kuat geser, perubahan volume, dan penurunan tanah. Persamaan tegangan vertikal efektif adalah sebagai berikut.

$\sigma^{\prime}=\gamma \mathrm{Z}$

$\gamma^{\prime}=\frac{\left(\mathrm{G}_{\mathrm{s}}-1\right) \gamma_{\mathrm{w}}}{1+\mathrm{e}}$

$\gamma_{\mathrm{d}}=\frac{\mathrm{G}_{\mathrm{s}} \gamma_{\mathrm{w}}}{1+\mathrm{e}}$

dimana:

$\sigma^{\prime} \quad=$ tegangan vertikal efektif $\left(\mathrm{kN} / \mathrm{m}^{2}\right)$;

$\gamma=$ berat volume tanah $\left(\mathrm{kN} / \mathrm{m}^{3}\right)$, untuk lapisan yang terletak di bawah MAT (Muka Air Tanah) digunakan $\gamma^{\prime}$ (berat volume tanah efektif) dan untuk lapisan yang terletak di atas MAT digunakan $\gamma_{\mathrm{d}}$ (bera $\mathrm{t}$ volume tanah kering);

$\mathrm{z} \quad=$ kedalaman lapisan $\operatorname{tanah}(\mathrm{m})$;

$\mathrm{G}_{\mathrm{s}} \quad=$ berat jenis tanah;

e $\quad$ angka pori; dan

$\gamma_{\mathrm{w}}=$ berat volume air $\left(1 \mathrm{t} / \mathrm{m}^{3}\right.$ atau $\left.9,81 \mathrm{kN} / \mathrm{m}^{3}\right)$.

\subsection{Kapasitas dukung tiang pancang}

Menurut Hardiyatmo [6] daya dukung tiang dipengaruhi oleh kondisi tanah. Faktor lain seperti bahan tiang, dan proses pembuatan tiang juga dapat memengaruhi kapasitas dukung tiang.

\subsubsection{Kapasitas dukung ultimit}

Menurut Bowles [7] daya dukung ultimit tiang pancang adalah akumulasi tahanan ujung bawah ultimit dan tahanan gesek ultimit. Persamaan kapasitas dukung ultimit dapat dilihat pada persamaan berikut.

$\mathrm{Q}_{\mathrm{u}}=\mathrm{Q}_{\mathrm{b}}+\mathrm{Q}_{\mathrm{s}}$

dimana:

$\mathrm{Q}_{\mathrm{u}} \quad$ = daya dukung ultimit netto $(\mathrm{kN})$;

$\mathrm{Q}_{\mathrm{b}} \quad=$ tahanan ujung bawah ultimit $(\mathrm{kN})$; dan

$\mathrm{Q}_{\mathrm{s}} \quad=$ tahanan gesek ultimit $(\mathrm{kN})$.

\subsubsection{Kapasitas dukung izin}

Menurut Tomlinson [8] daya dukung izin diperoleh dari daya dukung ultimit dibagi dengan faktor aman. Berikut persamaan daya dukung izin.

$\mathrm{Q}_{\mathrm{a}}=\frac{\mathrm{Q}_{\mathrm{u}}}{\mathrm{SF}}$

dimana:

$\mathrm{Q}_{\mathrm{a}} \quad=$ daya dukung izin $(\mathrm{kN})$; dan

$\mathrm{SF} \quad=2,5$ (untuk tiang pancang dengan diameter $\leq 0,6 \mathrm{~m})$

\subsection{Kapasitas dukung tiang pancang metode statis}

Bowles [7] menyebutkan bahwa daya dukung pondasi tiang pancang dengan metode statis membutuhkan parameter tanah berupa sudut gesek dalam $(\varphi)$ dan kohesi (c). Terdapat beberapa metode statis yang dapat digunakan untuk menghitung tahanan ujung dan tahanan gesek tiang pancang.

\subsection{Tahanan ujung ultimit}

Menurut Bowles [7] ada beberapa metode statis yang dapat digunakan untuk memperoleh nilai tahanan ujung ultimit $\left(\mathrm{Q}_{\mathrm{b}}\right)$ pada tiang pancang. Salah satunya adalah metode Meyerhoff.

\subsubsection{Metode Meyerhoff}

Bowles [7] menyebutkan bahwa metode ini menggunakan faktor kapasitas dukung. Berikut persamaan tahanan ujung pada metode ini. Persamaan ini berlaku jika $\mathrm{Lb} / \mathrm{D}<(\mathrm{Lb} / \mathrm{D})_{\mathrm{cr}}$. 
$\left.\mathrm{Q}_{\mathrm{b}}=\mathrm{A}_{\mathrm{b}}\left[\mathrm{c}_{\mathrm{b}} \mathrm{N}^{\prime}{ }_{\mathrm{c}}+\eta \sigma^{\prime}\left(\mathrm{N}_{\mathrm{q}}^{\prime}-1\right)\right] \leq \mathrm{A}_{\mathrm{b}}\left(50 \mathrm{~N}^{\prime}{ }_{\mathrm{q}}\right) \tan \varphi 6\right)$

dimana:

$A_{b} \quad=$ luas penampang ujung bawah tiang $\left(\mathrm{m}^{2}\right)$;

$\mathrm{c}_{\mathrm{b}} \quad=$ kohesi tanah di sekitar ujung tiang $\left(\mathrm{kN} / \mathrm{m}^{2}\right)$;

$\eta \quad=$ diambil nilainya 1 ;

$\varphi \quad=$ sudut gesek $\left({ }^{\circ}\right)$;

$\mathrm{L}_{\mathrm{b}} \quad$ = panjang lapisan tumpuan ujung tiang;

$\mathrm{D} \quad=$ diameter tiang pancang;

$\left(\mathrm{L}_{\mathrm{b}} / \mathrm{D}\right)_{\mathrm{cr}}=\mathrm{L}_{\mathrm{b}} / \mathrm{D}$ kritis; dan

$\mathrm{N}^{\prime}, \mathrm{N}_{\mathrm{q}}$ = faktor-faktor daya dukung, dimana Menurut Meyerhoff [9] pada jenis lapisan tanah yang memiliki nilai kohesi (c) dan sudut gesek $(\varphi)$, maka nilai faktor-faktor daya dukung adalah $\mathrm{N}^{\prime}{ }_{\mathrm{i}}=\left(\mathrm{N}_{\mathrm{i}}+\mathrm{N}^{\prime}{ }_{\mathrm{i}}\right) / 2$.

Gambaran $\mathrm{L}_{\mathrm{b}}$ pada tiang dapat dilihat pada Gambar 1.

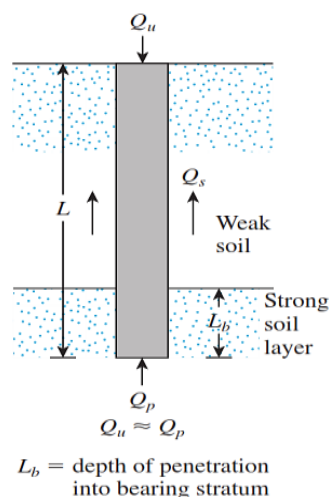

Gambar 1. Gambaran $L_{b}$ pada tiang Sumber: Das, 2011

Grafik faktor-faktor daya dukung pada pondasi dalam menurut Meyerhoff serta nilai $\left(\mathrm{L}_{\mathrm{b}} / \mathrm{D}\right)_{\mathrm{cr}}$ dapat dilihat pada Gambar 2.

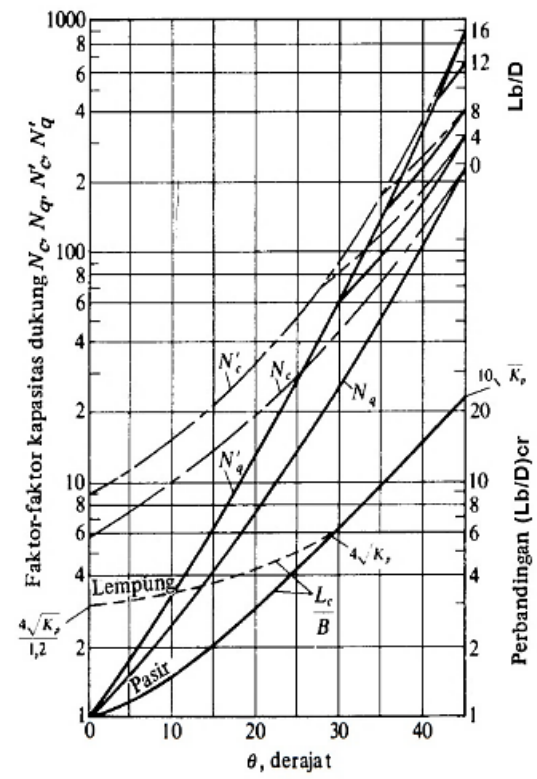

Gambar 2. Grafik faktor-faktor daya dukung pada pondasi dalam menurut Meyerhoff

Sumber: Meyerhoff, 1976

\subsection{Tahanan gesek ultimit}

Menurut Bowles [7] ada beberapa metode statis yang dapat digunakan untuk menghitung tahanan gesek ultimit $\left(Q_{s}\right)$ tiang pancang. Pada penelitian ini, metode yang dipilih adalah metode Alpha, Lamda, dan Beta.

\subsubsection{Metode Alpha}

Tomlinson [10] menyebutkan bahwa metode ini menggunakan faktor adhesi $(\alpha)$ untuk menghitung tahanan gesek tiang pancang. Persamaannya adalah sebagai berikut.

$\mathrm{Q}_{\mathrm{s}}=\Sigma \mathrm{A}_{\mathrm{s}}\left(\alpha \mathrm{c}_{\mathrm{u}}+\mathrm{K}_{\mathrm{o}} \sigma^{\prime} \tan \delta\right)$

$\mathrm{K}_{\mathrm{o}}=1-\sin \varphi$

$\delta=2 \varphi / 3$

dimana:

$\mathrm{A}_{\mathrm{s}} \quad=$ luas selimut tiang $\left(\mathrm{m}^{2}\right)$;

$\alpha \quad=$ faktor adhesi;

$\mathrm{c}_{\mathrm{u}} \quad=$ kohesi tidak terdrainase sepanjang tiang atau nilai kohesi $\left(\mathrm{kN} / \mathrm{m}^{2}\right)$;

$\mathrm{K}_{\mathrm{o}} \quad=$ koefisien tekanan tanah; dan

$\delta=$ sudut gesek antara bahan pondasi dengan tanah atau batuan.

Grafik faktor adhesi $(\alpha)$ untuk tiang pancang dapat dilihat pada Gambar 3.

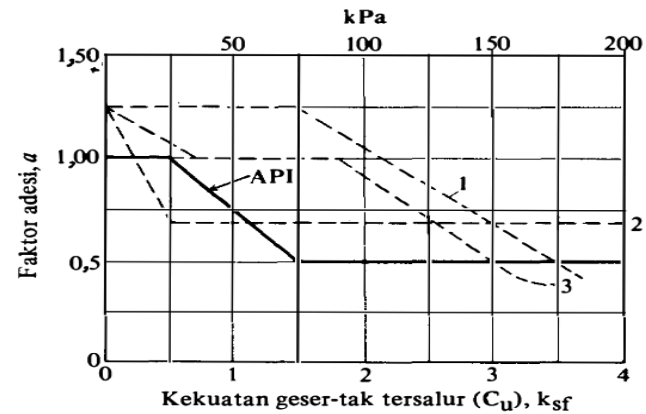

Gambar 3. Grafik hubungan faktor adhesi $(\alpha)$ dengan kohesi (c)

Sumber: Tomlinson, 1971

\subsubsection{Metode Lamda}

Menurut Vijayvergiya dan Focht [11] metode ini menggunakan koefisien $\lambda$ untuk memperoleh tahanan gesek tiang pancang. Persamaan tahanan gesek ultimit metode ini adalah sebagai berikut.

$\mathrm{Q}_{\mathrm{s}}=\Sigma \mathrm{A}_{\mathrm{s}}\left[\lambda\left(\sigma^{\prime}+2 \mathrm{c}_{\mathrm{u}}\right)\right]$

dimana:

$\lambda \quad=$ koefisien gesek dinding. 


\subsubsection{Metode Beta}

Menurut Burland [12] digunakan koefisien tekanan tanah lateral $\left(\mathrm{K}_{\mathrm{o}}\right)$ untuk menghitung tahanan gesek dengan metode ini. Berikut persamaannya.

$\mathrm{Q}_{\mathrm{s}}=\Sigma \mathrm{A}_{\mathrm{s}}\left(\mathrm{K}_{\mathrm{o}} \sigma^{\prime} \tan \delta\right)$

\section{Metodologi Penelitian}

Bab ini berisi prosedur yang dilakukan pada penelitian. Hal-hal yang diuraikan antara lain adalah pengumpulan data serta metode perhitungan.

\subsection{Tahapan Penelitian}

Penelitian ini menggunakan tahapan penelitian agar diketahui hal-hal yang harus dilakukan. Tahapan tersebut dapat dilihat pada Gambar 4.

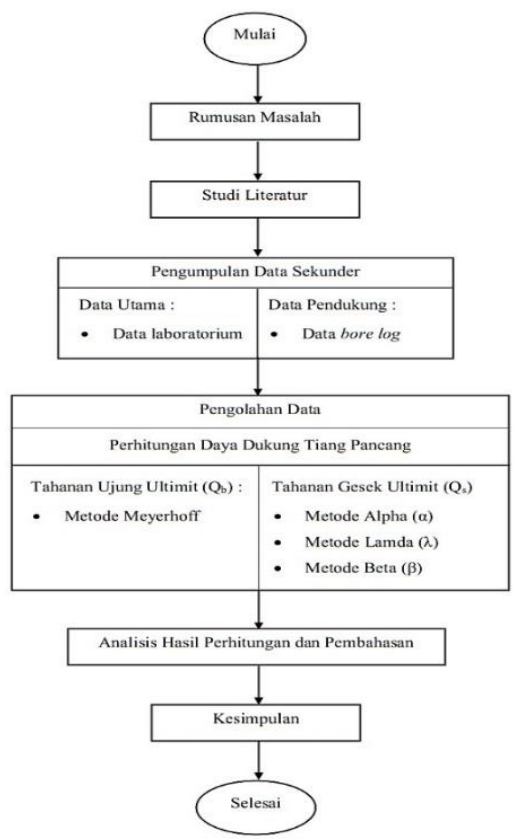

Gambar 4. Diagram alir penelitian

Berdasarkan Gambar 4, ada 2 jenis data yang digunakan, yaitu data utama dan pendukung. Sedangkan perhitungan daya dukung dilakukan dengan 5 metode, 1 metode untuk menghitung tahanan ujung, dan 3 metode untuk tahanan gesek.

\subsection{Pengumpulan Data}

Data yang digunakan pada penelitian ini merupakan data sekunder berupa data laboratorium berisi index properties dan parameter kuat geser tanah terhadap sampel tanah dari 2 bore hole, yaitu $\mathrm{BH}-01$ dan BH-03. Data lain seperti spesifikasi tiang pancang untuk mengetahui diameter tiang belum ada, maka digunakan diameter tiang rencana, yaitu $0,4 \mathrm{~m}$, dan 0,5 m. Data laboratorium untuk $\mathrm{BH}-01$ dan $\mathrm{BH}-03$ dapat dilihat pada Tabel 1 dan 2 .
Tabel 1. Data laboratorium BH-01

\begin{tabular}{|c|c|c|c|c|c|}
\hline $\begin{array}{c}\text { Depth } \\
(\mathrm{m})\end{array}$ & $\mathrm{G}_{\mathrm{s}}$ & $\begin{array}{c}\gamma_{\mathrm{d}} \\
(\mathrm{g} / \\
\left.\mathrm{cm}^{3}\right)\end{array}$ & $\begin{array}{c}\mathrm{W} \\
(\%)\end{array}$ & $\begin{array}{c}\varphi \\
\left({ }^{\circ}\right)\end{array}$ & $\begin{array}{c}\mathrm{c} \\
(\mathrm{kg} / \\
\left.\mathrm{cm}^{2}\right)\end{array}$ \\
\hline 6 & 2,622 & 1,715 & 12,21 & 34,69 & 0,008 \\
\hline 10 & 2,504 & 1,079 & 47,10 & 26,00 & 0,054 \\
\hline 16 & 2,618 & 1,467 & 26,95 & 29,01 & 0,024 \\
\hline 20 & 2,704 & 1,628 & 20,91 & 32,63 & 0,023 \\
\hline 30 & 2,665 & 1,655 & 21,14 & 33,75 & 0,028 \\
\hline
\end{tabular}

Tabel 2. Data laboratorium BH-03

\begin{tabular}{|c|c|c|c|c|c|}
\hline $\begin{array}{c}\text { Depth } \\
(\mathrm{m})\end{array}$ & $\mathrm{G}_{\mathrm{s}}$ & $\begin{array}{c}\gamma_{\mathrm{d}} \\
(\mathrm{g} / \\
\left.\mathrm{cm}^{3}\right)\end{array}$ & $\begin{array}{c}\mathrm{W} \\
(\%)\end{array}$ & $\begin{array}{c}\varphi \\
\left({ }^{\circ}\right)\end{array}$ & $\begin{array}{c}\mathrm{c} \\
(\mathrm{kg} / \\
\left.\mathrm{cm}^{2}\right)\end{array}$ \\
\hline 6 & 2,685 & 1,595 & 23,69 & 32,17 & 0,056 \\
\hline 10 & 2,644 & 1,398 & 33,91 & 29,01 & 0,165 \\
\hline 16 & 2,657 & 1,190 & 44,78 & 5,64 & 0,029 \\
\hline 20 & 2,728 & 1,578 & 19,77 & 29,34 & 0,036 \\
\hline 26 & 2,700 & 1,457 & 22,19 & 34,21 & 0,040 \\
\hline 30 & 2,753 & 1,541 & 25,29 & 37,76 & 0,051 \\
\hline
\end{tabular}

\subsection{Deskripsi lapisan tanah}

Profil lapisan tanah diperoleh dari data bore $\log$ yang dapat dilihat pada Tabel 3 dan 4. Pada tabel tersebut diuraikan nilai N-SPT serta jenis lapisan tanah pada setiap bore hole yang ditinjau.

Tabel 3. Profil lapisan tanah BH-01

\begin{tabular}{|c|c|c|}
\hline $\begin{array}{c}\text { Depth } \\
(\mathrm{m})\end{array}$ & $\begin{array}{c}\text { N-SPT } \\
\text { rerata }\end{array}$ & $\begin{array}{c}\text { Jenis } \\
\text { lapisan }\end{array}$ \\
\hline $0-2$ & 0 & $\begin{array}{c}\text { Lempung sangat lembek } \\
\text { (MAT }=1,4 \mathrm{~m})\end{array}$ \\
\hline $2-6$ & 17 & Pasir \\
\hline $6-8$ & 35 & Pasir padat \\
\hline $8-14$ & 12 & Lempung \\
\hline $14-18$ & 24 & Pasir \\
\hline $18-30$ & $>60$ & Pasir sangat padat \\
\hline
\end{tabular}

Tabel 4. Profil lapisan tanah BH-03

\begin{tabular}{|c|c|c|}
\hline $\begin{array}{c}\text { Depth } \\
(\mathrm{m})\end{array}$ & $\begin{array}{c}\text { N-SPT } \\
\text { rerata }\end{array}$ & $\begin{array}{c}\text { Jenis } \\
\text { lapisan }\end{array}$ \\
\hline $0-2$ & 0 & Lempung sangat lembek \\
\hline $2-4$ & 16 & Lempung kaku \\
\hline $4-6$ & 55 & Pasir sangat padat \\
\hline $6-8$ & 39 & Pasir padat \\
\hline $8-14$ & 10 & Pasir lepas \\
\hline $14-16$ & 57 & Pasir sangat padat \\
\hline $16-18$ & 21 & Lempung kaku \\
\hline $18-24$ & $>60$ & Pasir sangat padat \\
\hline $24-26$ & 43 & Pasir padat \\
\hline $26-30$ & 17 & Lempung kaku \\
\hline
\end{tabular}

Berdasarkan Tabel 3 dan 4 serta ketersediaan data laboratorium, perhitungan tahanan ujung $(\mathrm{Qb}) \mathrm{BH}-01$ dapat dilakukan pada kedalaman $20 \mathrm{~m}$ dan $30 \mathrm{~m}$, sedangkan BH-03 pada kedalaman $20 \mathrm{~m}$ dan $26 \mathrm{~m}$. 


\subsection{Metode perhitungan daya dukung statis}

Perhitungan daya dukung dilakukan dengan 4 metode, Meyerhoff untuk menghitung tahanan ujung, serta metode Alpha, Lamda, dan Beta untuk menghitung tahanan gesek. Daya dukung ultimit diperoleh dari 3 kombinasi metode, yaitu Meyerhoff - Alpha, Meyerhoff - Lamda, dan Meyerhoff - Beta, setelah itu dihitung daya dukung izin $\left(\mathrm{Q}_{\mathrm{a}}\right)$.

\section{Hasil dan Pembahasan}

Bab ini berisi penjelasan mengenai hasil yang dicapai dalam penelitian Ini serta pembahasan mengenai hasil tersebut. Hasil yang diperoleh dari penelitian ini menjadi jawaban tujuan penelitian ini.

\subsection{Hasil perhitungan}

\subsubsection{Tahanan ujung ultimit metode Meyerhoff}

Hasil tahanan ujung ultimit metode Meyerhoff diperlihatkan pada Tabel dan grafik Gambar 5. $\mathrm{Q}_{\mathrm{b}}$ terkecil diperoleh pada BH-03 diameter tiang 0,4 m kedalaman 20 m dengan nilai 13,900 ton, sedangkan $\mathrm{Q}_{\mathrm{b}}$ terbesar pada $\mathrm{BH}-03$ diameter tiang 0,5 m kedalaman $26 \mathrm{~m}$ dengan nilai 55,174 ton.

Tabel 5. Tahanan ujung ultimit metode Meyerhoff

\begin{tabular}{|c|c|c|c|}
\hline \multirow{2}{*}{$\begin{array}{c}\text { Bore } \\
\text { hole }\end{array}$} & \multirow{2}{*}{$\begin{array}{c}\text { Depth } \\
(\mathrm{m})\end{array}$} & \multicolumn{2}{|c|}{$\begin{array}{c}\text { Tahanan ujung ultimit } \\
\mathrm{Q}_{\mathrm{b}} \text { (ton) }\end{array}$} \\
\cline { 3 - 4 } & & Diameter $0,4 \mathrm{~m}$ & Diameter $0,5 \mathrm{~m}$ \\
\hline $\mathrm{BH}-$ & 20 & 25,380 & 39,656 \\
\cline { 2 - 4 } & 30 & 33,150 & 51,797 \\
\hline $\mathrm{BH}-$ & 20 & 13,900 & 21,718 \\
\cline { 2 - 4 } 03 & 26 & 35,311 & 55,174 \\
\hline
\end{tabular}

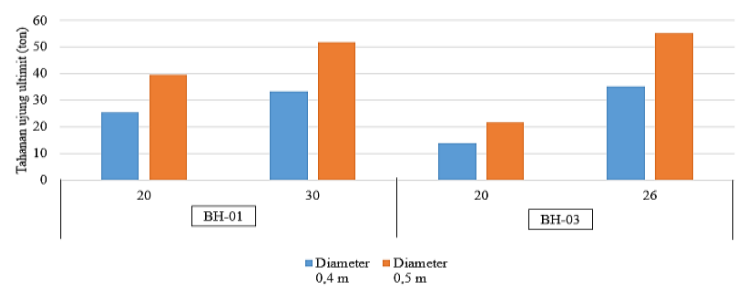

Gambar 5. Grafik tahanan ujung metode Meyerhoff

\subsubsection{Tahanan gesek ultimit metode Alpha}

Hasil tahanan gesek ultimit metode Alpha diperlihatkan pada Tabel dan grafik Gambar 6. $\mathrm{Q}_{\mathrm{s}}$ terkecil diperoleh pada BH-01 diameter tiang 0,4 m kedalaman $6 \mathrm{~m}$ dengan nilai 10,716 ton, sedangkan $\mathrm{Q}_{\mathrm{s}}$ terbesar pada BH-01 diameter tiang 0,5 m kedalaman $30 \mathrm{~m}$ dengan nilai 271,614 ton.

Tabel 6. Tahanan gesek ultimit metode Alpha

\begin{tabular}{|c|c|c|c|}
\hline Bore & Depth & \multicolumn{2}{|c|}{ Tahanan gesek ultimit (ton) } \\
\cline { 3 - 4 } hole & $(\mathrm{m})$ & Diameter $0,4 \mathrm{~m}$ & Diameter 0,5 m \\
\hline BH- & 6 & 10,716 & 13,396 \\
\cline { 2 - 4 } 01 & 10 & 28,564 & 35,705 \\
\hline
\end{tabular}

\begin{tabular}{|c|c|c|c|}
\hline Bore & \multirow{2}{*}{$\begin{array}{c}\text { Depth } \\
\text { hole }\end{array}$} & \multicolumn{2}{|c|}{ Tahanan gesek ultimit (ton) } \\
\cline { 2 - 4 } & Diameter 0,4 m & Diameter 0,5 m \\
\hline \multirow{2}{*}{$\begin{array}{c}\text { BH- } \\
01\end{array}$} & 16 & 60,545 & 75,681 \\
\cline { 2 - 4 } & 20 & 95,607 & 119,508 \\
\cline { 2 - 4 } & 30 & 217,291 & 271,614 \\
\hline \multirow{4}{*}{$\begin{array}{c}\text { BH- } \\
03\end{array}$} & 6 & 14,282 & 17,852 \\
\cline { 2 - 4 } & 10 & 45,155 & 56,444 \\
\cline { 2 - 4 } & 16 & 23,946 & 29,932 \\
\cline { 2 - 4 } & 20 & 96,501 & 120,626 \\
\cline { 2 - 4 } & 26 & 161,704 & 202,130 \\
\hline
\end{tabular}

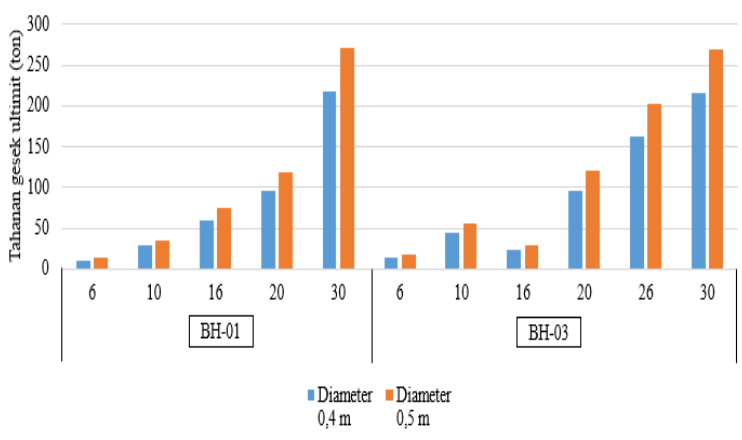

Gambar 6. Grafik tahanan gesek metode Alpha

\subsubsection{Tahanan gesek ultimit metode Lamda}

Hasil tahanan gesek metode Lamda terlihat pada Tabel dan grafik Gambar 7. Q $\mathrm{Q}_{\mathrm{s}}$ terkecil diperoleh pada BH-01 diameter tiang 0,4 m kedalaman $6 \mathrm{~m}$ dengan nilai 16,568 ton, sedangkan $\mathrm{Q}_{\mathrm{s}}$ terbesar pada $\mathrm{BH}-01$ diameter tiang $0,5 \mathrm{~m}$ kedalaman $30 \mathrm{~m}$ dengan nilai 207,367 ton.

Tabel 7. Tahanan gesek ultimit metode Lamda

\begin{tabular}{|c|c|c|c|}
\hline \multirow{2}{*}{$\begin{array}{l}\text { Bore } \\
\text { hole }\end{array}$} & \multirow{2}{*}{$\begin{array}{c}\text { Depth } \\
\text { (m) }\end{array}$} & \multicolumn{2}{|c|}{ Tahanan gesek ultimit (ton) } \\
\hline & & Diameter $0,4 \mathrm{~m}$ & Diameter $0,5 \mathrm{~m}$ \\
\hline \multirow{2}{*}{$\begin{array}{c}\text { BH- } \\
01\end{array}$} & 6 & 16,568 & 20,710 \\
\hline & 10 & 33,069 & 41,336 \\
\hline \multirow{3}{*}{$\begin{array}{c}\mathrm{BH}- \\
01\end{array}$} & 16 & 61,985 & 77,481 \\
\hline & 20 & 87,514 & 109,392 \\
\hline & 30 & 165,894 & 207,367 \\
\hline \multirow{6}{*}{$\begin{array}{c}\mathrm{BH}- \\
03\end{array}$} & 6 & 18,643 & 23,304 \\
\hline & 10 & 42,358 & 52,947 \\
\hline & 16 & 61,865 & 77,332 \\
\hline & 20 & 87,620 & 109,525 \\
\hline & 26 & 129,197 & 161,496 \\
\hline & 30 & 162,137 & 202,671 \\
\hline
\end{tabular}

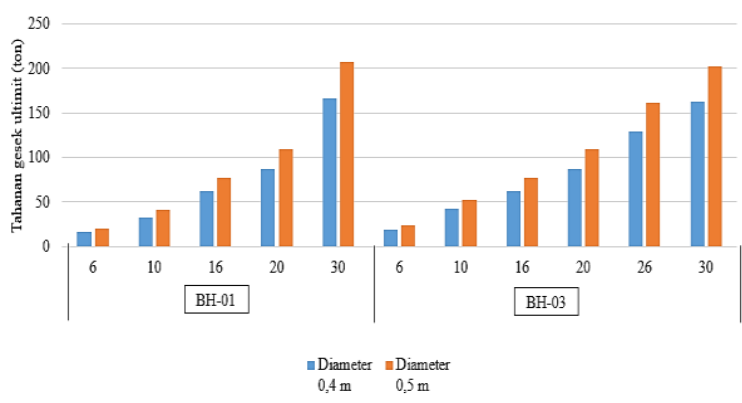

Gambar 7. Grafik tahanan gesek metode Lamda 


\subsubsection{Tahanan gesek ultimit metode Beta}

Tahanan gesek metode Beta terlihat pada Tabel dan Gambar 8. $\mathrm{Q}_{\mathrm{s}}$ terkecil diperoleh pada $\mathrm{BH}-03$ diameter tiang 0,4 m kedalaman $6 \mathrm{~m}$ dengan nilai 10,055 ton, sedangkan $\mathrm{Q}_{\mathrm{s}}$ terbesar pada $\mathrm{BH}-01$ diameter tiang $0,5 \mathrm{~m}$ kedalaman $30 \mathrm{~m}$ dengan nilai 258,406 ton.

Tabel 8. Tahanan gesek ultimit metode Beta

\begin{tabular}{|c|c|c|c|}
\hline Bore & \multirow{2}{*}{$\begin{array}{c}\text { Depth } \\
\text { hole }\end{array}$} & \multicolumn{2}{|c|}{ Tahanan gesek ultimit (ton) } \\
\cline { 2 - 4 } & 6 & Diameter 0,4 m & Diameter 0,5 m \\
\hline \multirow{4}{*}{$\begin{array}{c}\text { BH- } \\
01\end{array}$} & 10 & 21,771 & 12,641 \\
\cline { 2 - 4 } & 16 & 55,714 & 27,214 \\
\cline { 2 - 4 } & 20 & 89,820 & 69,643 \\
\cline { 2 - 4 } & 30 & 206,725 & 112,275 \\
\hline \multirow{4}{*}{ BH- } & 6 & 10,055 & 1258,406 \\
\cline { 2 - 4 } 03 & 10 & 24,400 & 30,509 \\
\cline { 2 - 4 } & 16 & 18,109 & 22,636 \\
\cline { 2 - 4 } & 20 & 87,444 & 109,305 \\
\cline { 2 - 4 } & 26 & 148,621 & 185,777 \\
\hline & 30 & 196,711 & 245,888 \\
\hline
\end{tabular}

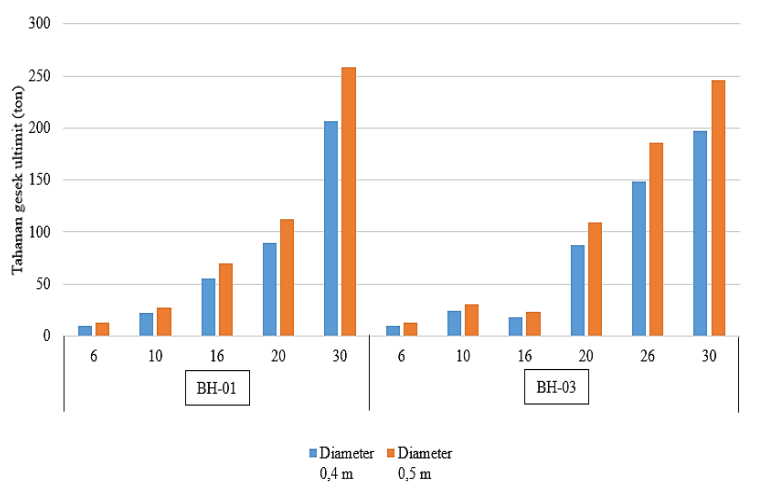

Gambar 8. Grafik tahanan gesek metode Beta

\subsubsection{Daya dukung metode Meyerhoff - Alpha}

Hasil daya dukung metode Meyerhoff - Alpha terlihat pada Tabel dan grafik Gambar 9. Daya dukung terkecil diperoleh pada $\mathrm{BH}-03$ diameter tiang 0,4 m kedalaman $20 \mathrm{~m}$ dengan $\mathrm{Q}_{\mathrm{u}}=110,401$ ton dan $\mathrm{Q}_{\mathrm{a}}=44,160$ ton, sedangkan daya dukung terbesar pada BH-01 diameter tiang 0,5 m kedalaman $30 \mathrm{~m}$ dengan $\mathrm{Q}_{\mathrm{u}}=323,412$ ton dan $\mathrm{Q}_{\mathrm{a}}=129,365$ ton.

Tabel 9. Daya dukung metode Meyerhoff - Alpha

\begin{tabular}{|c|c|c|c|c|}
\hline \multirow{2}{*}{$\begin{array}{l}\text { Bore } \\
\text { hole }\end{array}$} & \multirow{2}{*}{$\begin{array}{c}\text { Daya } \\
\text { Dukung }\end{array}$} & \multirow{2}{*}{$\begin{array}{l}\text { Depth } \\
(\mathrm{m})\end{array}$} & \multicolumn{2}{|c|}{ Daya dukung (ton) } \\
\hline & & & $\begin{array}{c}\text { Diameter } \\
0,4 \mathrm{~m}\end{array}$ & $\begin{array}{c}\text { Diameter } \\
0,5 \mathrm{~m}\end{array}$ \\
\hline \multirow{4}{*}{$\begin{array}{c}\mathrm{BH}- \\
01\end{array}$} & \multirow{2}{*}{$\mathrm{Q}_{\mathrm{u}}$} & 20 & 120,986 & 159,164 \\
\hline & & 30 & 250,442 & 323,412 \\
\hline & \multirow{2}{*}{$\mathrm{Q}_{\mathrm{a}}$} & 20 & 48,395 & 63,666 \\
\hline & & 30 & 100,177 & 129,365 \\
\hline \multirow{4}{*}{$\begin{array}{c}\mathrm{BH}- \\
03\end{array}$} & \multirow{2}{*}{$\mathrm{Q}_{\mathrm{u}}$} & 20 & 110,401 & 142,345 \\
\hline & & 26 & 197,015 & 257,303 \\
\hline & \multirow{2}{*}{$\mathrm{Q}_{\mathrm{a}}$} & 20 & 44,160 & 56,938 \\
\hline & & 26 & 78,806 & 102,921 \\
\hline
\end{tabular}

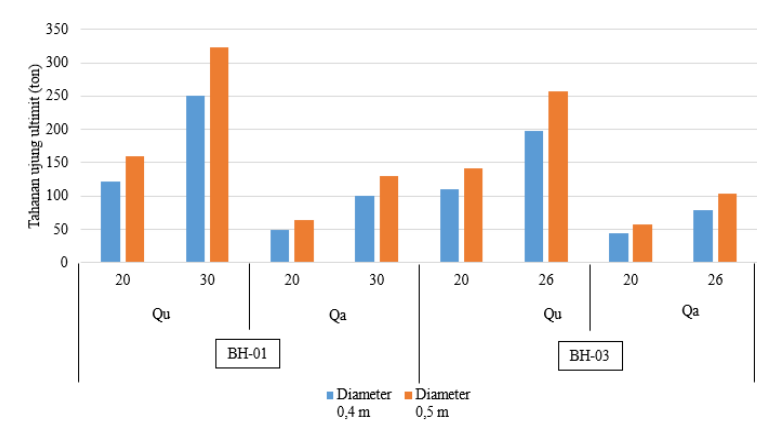

Gambar 9. Grafik daya dukung Meyerhoff Alpha

\subsubsection{Daya dukung metode Meyerhoff - Lamda}

Hasil daya dukung metode Meyerhoff - Lamda terlihat pada Tabel dan grafik Gambar 10. Daya dukung terkecil diperoleh pada $\mathrm{BH}-03$ diameter tiang 0,4 m kedalaman $20 \mathrm{~m}$ dengan $\mathrm{Q}_{\mathrm{u}}=101,519$ ton dan $\mathrm{Q}_{\mathrm{a}}=40,608$ ton, sedangkan daya dukung terbesar pada BH-01 diameter tiang 0,5 m kedalaman $30 \mathrm{~m}$ dengan $Q_{u}=259,165$ ton dan $Q_{a}=103,666$ ton.

Tabel 10. Daya dukung metode Meyerhoff Lamda

\begin{tabular}{|c|c|c|c|c|}
\hline \multirow{2}{*}{$\begin{array}{l}\text { Bore } \\
\text { hole }\end{array}$} & \multirow[b]{2}{*}{$\begin{array}{c}\text { Daya } \\
\text { Dukung }\end{array}$} & \multirow{2}{*}{$\begin{array}{l}\text { Depth } \\
\text { (m) }\end{array}$} & \multicolumn{2}{|c|}{ Daya dukung (ton) } \\
\hline & & & $\begin{array}{c}\text { Diameter } \\
0,4 \mathrm{~m}\end{array}$ & $\begin{array}{c}\text { Diameter } \\
0,5 \mathrm{~m}\end{array}$ \\
\hline \multirow{4}{*}{$\begin{array}{c}\mathrm{BH}- \\
01\end{array}$} & \multirow{2}{*}{$\mathrm{Qu}_{\mathrm{u}}$} & 20 & 112,894 & 149,048 \\
\hline & & 30 & 199,044 & 259,165 \\
\hline & \multirow{2}{*}{$\mathrm{Q}_{\mathrm{a}}$} & 20 & 45,157 & 59,619 \\
\hline & & 30 & 79,618 & 103,666 \\
\hline \multirow{4}{*}{$\begin{array}{c}\mathrm{BH}- \\
03\end{array}$} & \multirow{2}{*}{$\mathrm{Q}_{\mathrm{u}}$} & 20 & 101,519 & 131,243 \\
\hline & & 26 & 164,508 & 216,670 \\
\hline & \multirow{2}{*}{$\mathrm{Q}_{\mathrm{a}}$} & 20 & 40,608 & 52,497 \\
\hline & & 26 & 65,803 & 86,668 \\
\hline
\end{tabular}

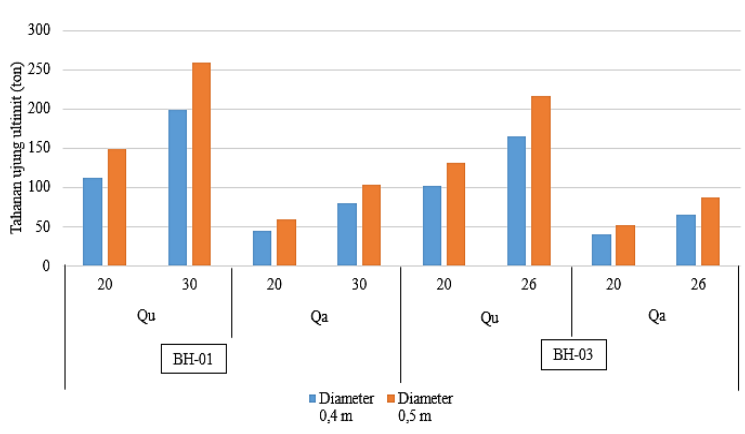

Gambar 10. Grafik daya dukung Meyerhoff Lamda

\subsubsection{Daya dukung metode Meyerhoff - Beta}

Hasil daya dukung metode Meyerhoff - Beta terlihat pada Tabel dan grafik Gambar 11. Daya dukung terkecil diperoleh pada $\mathrm{BH}-03$ diameter tiang 0,4 m kedalaman $20 \mathrm{~m}$ dengan $\mathrm{Q}_{\mathrm{u}}=101,344$ ton dan $\mathrm{Q}_{\mathrm{a}}=40,538$ ton, sedangkan daya dukung terbesar pada $\mathrm{BH}-01$ diameter tiang $0,5 \mathrm{~m}$ kedalaman $30 \mathrm{~m}$ dengan $\mathrm{Q}_{\mathrm{u}}=310,203$ ton dan $\mathrm{Q}_{\mathrm{a}}=124,081$ ton. 
Tabel 11. Daya dukung metode Meyerhoff - Beta

\begin{tabular}{|c|c|c|c|c|}
\hline \multirow[b]{2}{*}{$\begin{array}{l}\text { Bore } \\
\text { hole }\end{array}$} & \multirow[b]{2}{*}{$\begin{array}{c}\text { Daya } \\
\text { Dukung }\end{array}$} & \multirow[b]{2}{*}{$\begin{array}{l}\text { Depth } \\
\text { (m) }\end{array}$} & \multicolumn{2}{|c|}{ Daya dukung (ton) } \\
\hline & & & $\begin{array}{c}\text { Diameter } \\
0,4 \mathrm{~m}\end{array}$ & $\begin{array}{c}\text { Diameter } \\
0,5 \mathrm{~m}\end{array}$ \\
\hline \multirow{4}{*}{$\begin{array}{c}\mathrm{BH}- \\
01\end{array}$} & \multirow{2}{*}{$\mathrm{Q}_{\mathrm{u}}$} & 20 & 115,200 & 151,931 \\
\hline & & 30 & 239,875 & 310,203 \\
\hline & \multirow{2}{*}{$\mathrm{Q}_{\mathrm{a}}$} & 20 & 46,080 & 60,772 \\
\hline & & 30 & 95,950 & 124,081 \\
\hline \multirow{4}{*}{$\begin{array}{c}\mathrm{BH}- \\
03\end{array}$} & \multirow{2}{*}{$\mathrm{Q}_{\mathrm{u}}$} & 20 & 101,344 & 131,023 \\
\hline & & 26 & 183,932 & 240,950 \\
\hline & \multirow{2}{*}{$\mathrm{Q}_{\mathrm{a}}$} & 20 & 40,538 & 52,409 \\
\hline & & 26 & 73,573 & 96,380 \\
\hline
\end{tabular}

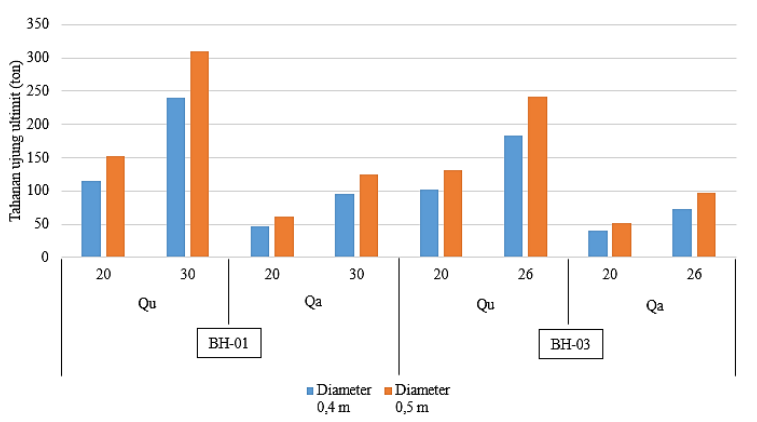

Gambar 11. Grafik daya dukung Meyerhoff Beta

\subsection{Pembahasan}

Nilai tahanan dan daya dukung semakin besar seiring bertambahnya diameter tiang. Pada tahanan gesek, umumnya meningkat seiring bertambah kedalaman, sebab semakin dalam lapisan, maka semakin besar tegangan vertikal efektif. Namun, pada metode Alpha dan Beta pada BH-03, terjadi penurunan tahanan gesek di kedalaman $16 \mathrm{~m}$, dan naik kembali pada kedalaman setelahnya, karena sudut gesek lapisan tersebut bernilai paling kecil dibanding lapisan lain. Namun, hal ini tidak terjadi pada metode Lamda. Perbedaan variabel pada setiap metode menghasilkan nilai tahanan yang berbeda. Pada tahanan ujung, nilai $\mathrm{Q}_{\mathrm{b}}$ meningkat seiring bertambahnya kedalaman, karena berdasarkan data laboratorium, sudut gesek pada kedalaman $30 \mathrm{~m}$ pada BH-01 dan kedalaman $26 \mathrm{~m}$ pada BH-03 lebih besar dibandingkan pada kedalaman $20 \mathrm{~m}$ pada kedua bore hole, sehingga semakin besar faktor daya dukungnya.

Daya dukung terkecil diperoleh dengan metode Meyerhoff - Beta pada BH-03 diameter tiang $0,4 \mathrm{~m}$ kedalaman $20 \mathrm{~m}$ dengan $\mathrm{Q}_{\mathrm{u}}=101,344$ ton dan $\mathrm{Q}_{\mathrm{a}}=40,538$ ton. Daya dukung terbesar diperoleh dengan metode Meyerhoff - Alpha pada BH-01 diameter tiang $0,5 \mathrm{~m}$ kedalaman $30 \mathrm{~m}$ dengan $\mathrm{Q}_{\mathrm{u}}=323,412$ ton dan $\mathrm{Q}_{\mathrm{a}}=129,365$ ton.

\section{Kesimpulan dan Saran}

Berdasarkan hasil penelitian, diperoleh kesimpulan dan saran. Kesimpulan menjawab tujuan dari penelitian, sedangkan saran berisi masukan untuk penelitian selanjutnya.

\subsection{Kesimpulan}

Semakin besar diameter tiang, semakin besar tahanan dan daya dukung yang diperoleh. Pada tahanan ujung, semakin besar sudut gesek maka semakin besar faktor-faktor daya dukungnya dan semakin besar $\mathrm{Q}_{b}$ yang diperoleh. Pada tahanan gesek, semakin dalam lapisan tanah, maka semakin besar tegangan vertikal efektifnya dan semakin besar $\mathrm{Q}_{s}$ yang diperoleh. Secara umum, tahanan gesek metode Alpha lebih besar dibandingkan Lamda dan Beta, sehingga daya dukung terbesar diperoleh pada metode Meyerhoff - Alpha dengan $\mathrm{Q}_{\mathrm{u}}=323,412$ ton dan $\mathrm{Q}_{\mathrm{a}}=129,365$ ton, sedangkan daya dukung terkecil diperoleh pada metode Meyerhoff - Beta dengan $\mathrm{Q}_{\mathrm{u}}=101,344$ ton dan $\mathrm{Q}_{\mathrm{a}}=40,538$ ton.

\subsection{Saran}

Sebelum memilih metode yang digunakan dalam perhitungan kapasitas dukung suatu pondasi, hendaknya melihat ketersediaan data yang ada. Data yang digunakan sesuai dengan metode yang dipilih harus lengkap untuk menjamin hasil perhitungan.

\section{Daftar pustaka}

[1] Sosrodarsono, S. 1987, Pedoman Perencanaan Pembebanan untuk Rumah dan Gedung, Jakarta, Departemen Pekerjaan Umum.

[2] Bowles, J. E. 1997, Analisis dan Desain Pondasi Jilid I Edisi Keempat, Jakarta, Erlangga.

[3] Hardiyatmo, H. C. 2018. Analisis dan Perancangan Pondasi II Edisi Keempat. Yogyakarta: Gadjah Mada University Press.

[4] Sardjono, H. S. 1988, Pondasi Tiang Pancang Jilid 1, Surabaya, Sinar Wijaya.

[5] Hardiyatmo, H. C. 2002, Mekanika Tanah I, Yogyakarta, Gajah Mada University Press.

[6] Hardiyatmo, H. C. 2008, Teknik Fondasi II, Yogyakarta, Beta Offset.

[7] Bowles, J. E. 1997, Analisis dan Desain Pondasi Jilid II Edisi Keempat, Jakarta, Erlangga.

[8] Tomlinson, M. J. 1977, Pile Design and Construction Practice, Lechworth, The Garden City Press Limited.

[9] Meyerhoff, G. G. 1976, Bearing Capacity and Settlement of Pile Foundations, Journal of Geotechnical Eng. Div. ASCE, Vol. 102, No. GT3, pp.197-228.

[10] Tomlinson, M. J. 1971, Some Effect on Pile Driving on Skin Friction, Proceeding ICE Conference Behavior of Piles, London, pp.107114.

[11] Vijayvergiya, V. N. and Focht, J. A. Jr. 1972, A New Way to Predict the Capacity of Piles in Clay, Proc. Offshore Technology Conference, Houston, TX, May.

[12] Burland, J. 1973, Shaft Friction of Piles in Clay, A Simple Fundamental Approach, Ground Engineering, Vol. 6, No. 3, pp.30-42. 